\title{
Customer's satisfaction on service quality at Vietnam Technological and Commercial Joint Stock Bank - An Giang Branch
}

\author{
Tran Minh Hieu ${ }^{1}{ }^{*}$, Nguyen Duong Ngoc Mai Chi ${ }^{2}$
}

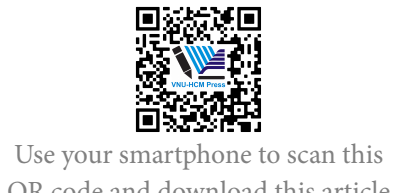

QR code and download this article
${ }^{1}$ An Giang University, VNU-HCM. NB105, 18 Ung Van Khiem Street, Dong Xuyen Ward, Long Xuyen City, An Giang Province, Vietnam

${ }^{2}$ Viet Capital Bank - An Giang Branch, 350 Nguyen Hue Street, Nui Sap Town, Thoai Son District, An Giang Province, Vietnam

\section{Correspondence}

Tran Minh Hieu, An Giang University, VNU-HCM. NB105, 18 Ung Van Khiem Street, Dong Xuyen Ward, Long Xuyen City, An Giang Province, Vietnam

Email: tmhieu@agu.edu.vn

\section{History}

- Received: 02/01/2020

- Accepted: 17/5/2020

- Published: 11/9/2020

DOI : 10.32508/stdjelm.v4i3.657

\section{Check for updates}

\section{Copyright}

(c) VNU-HCM Press. This is an openaccess article distributed under the terms of the Creative Commons Attribution 4.0 International license.

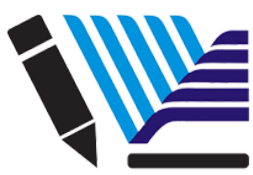

VNU-HCM Press

ABSTRACT

This study applied SERVQUAL scale of Parasuraman et al to measure factors affecting customer satisfaction on service quality at Vietnam Technological and Commercial Joint Stock Bank - An Giang Branch (Techcombank An Giang). The study was conducted to survey 207 customers who have been using the service at Techcombank An Giang. The survey results were analyzed by the Cronbach's Alpha reliability test method, then used Exploratory factor analysis (EFA) to verify and evaluate the scale of service quality. The results of the regression analysis show that customer's satisfaction about service quality at Techcombank An Giang includes four factors: The factor with the highest level is the Empathy with Beta $=0.253$, the second of factor is the Responsibility with Beta $=0.248$, ranked third in the influence level is the Tangible with Beta $=0.235$, and the lowest impact level is the Reliability with Beta $=0.144$. The research also uses statistical methods to describe and test the differences of demographic factors with customer's satisfactionon service quality.The analysis results show that there is no difference between customer's satisfaction on service quality and factors such as gender, age, income, number of transaction banks, regular transaction banks, and time to use the service at Techcombank An Giang. Through the research results, the author would like to propose some ideas to improve the quality of services, thereby attracting new customers and importantly, keeping traditional customers because the development orientation of Techcombank is to take care of old customers to cross sell other products of the bank. The Stud results offer a basis for the branch to identify the factors influencing customer satisfaction on their service quality, thereby having an appropriate strategy to improve customer satisfaction.

Key words: Customer's satisfaction, Techcombank - An Giang, service quality

\section{INTRODUCTION}

The Vietnamese banking system is entering a new competition in service development with the goal of bringing more utilities, based on modern banking technology, to attract customers and minimize risks. It can be said that customer is a decisive factor in the existence and development of banks, so they always consider their customer-oriented business strategy as the most important business strategy.

Service quality is a factor leading to the bank's success, many economists believe that the most competitive trend that shapes the business strategy is service quality. The quality of services helps increase profits, sales, differentiate products, and customer loyalty, thereby have positive feedback. How to satisfy customer satisfaction when their needs are always changing? This is the matter that banks try to deal with all their abilities to grow more and more.

Techcombank - An Giang was established on November 2, 2007 and officially operated on January 11, 2008. During its operation with the goal of maximizing bank profits, the bank has continuously developed and achieved retty good results. However, the low growth rate was due to the low number of customers, which affected the business goals and business results of Techcombank - An Giang. Does the quality of service at Techcombank - An Giang affect the number of customers? This is an issue that needs attention from bank leaders and appropriate solutions. Therefore, researching customer's satisfaction about service quality at Techcombank is a very important issue that must be conducted regularly to be able to meet customer needs. From there, we can serve our customers in the best way, making them really satisfied when doing transactions at the bank, contributing to the goal that the bank has set. Core values of Techcombank are "Customer First" and "Continuous improvement". They have been striving to improve its operational efficiency and customer service quality to become the number one bank in Vietnam.

\section{THEORY}

\section{Service and service quality}

Due to the complex, diverse and intangible nature of the service, researchers have not yet come up with a 
unified definition of this concept.

According to Parasuraman, Zeithaml, and Berry $(1988)^{1}$, service has four important characteristics, greatly influencing the design of effective service operation programs, Intangibility, Heterogeneity, Perishability and Inseparability. ervices are activities or benefits that businesses can offer to customers in order to establish, strengthen and expand long-term relationships and cooperation with customers (Armstrong, Adam, Denize, \& Kotler, 2014) ${ }^{2}$. In recent years, the service concept in the field of quality management has been agreed upon in accordance with ISO 8402: 1999: services are the results created to meet customer's requirements by contacting activities between suppliers. Supplier's internal and internal operations.

Service quality is a service that meets the needs and expectations of customers. Whether or not the service is good, it does not depend on the service provider through attitudes, behaviors, service spirit, appearance, customer contact, etc. To create good service, there must have an intersection between technical quality and functional quality (Asubonteng, McCleary, \& Swan, 1996) ${ }^{3}$. Although there are many different concepts of service quality, the quality of service includes the following characteristics: superiority, specificity, supply, satisfaction and value creation.

\section{Customer satisfaction \\ Define}

According to Bachelet $(1992)^{4}$, customer satisfaction is an emotional response of customers to their experience of a product or service. Oliva, Oliver, and Bearden $(1995)^{5}$ think that the difference, or the relationship of the value of products and services that customers receive compared to previous products and services, will show customer satisfaction. Similarly, Oliver $(1997)^{6}$ stated that customer satisfaction is the response of consumers to the fulfillment of their wishes. In this view, Zeithaml, Bitner, Gremler, and Pandit $(2000)^{7}$ claim that customer satisfaction is the evaluation of customers through a product or service that meets their wishes and requirements. This concept specifies customer satisfaction as a measurement based on a product or service. Satisfaction is the level of a person's state, derived from comparing the results obtained from the product and his expectations (Philip, Gary, John, \& Veronica, 2001) ${ }^{8}$. Customer satisfaction is the response of consumers to estimating the difference between previous expectations (or standards for performance) and the actual performance of the product as a accepted after using it (Tse \& Wilton,
1988) ${ }^{9}$. Customer satisfaction is a customer assessment of a product or service that meets the needs and expectations of the widely used SERVQUAL model (Asubonteng et al., 1996) ${ }^{3}$.

\section{The relationship between service quality and customer satisfaction}

Satisfaction and service quality are different but closely related concepts. Service quality is an objective concept that is valuable and aware. Satisfaction, meanwhile, is a combination of subjective components, based on feelings and emotions (Shemwell, Yavas, \& Bilgin, 1998) ${ }^{10}$. Service quality is the most influential factor on customer satisfaction (Cronin Jr \& Taylor, 1992 $)^{11}$. Service quality and satisfaction are closely related, in which the quality of service is the one that creates first and then determines customer's satisfaction.

Research by Zeithaml et al. $(2000)^{7}$ on the relationship between service quality and customer satisfaction also shows that the overall relationship of satisfaction includes service quality, product quality and price quality. In addition, satisfaction is influenced by situational factors and personal factors. Research by Curry and Sinclair (2002) ${ }^{12}$ also shows the relationship between service quality and customer satisfaction. Accordingly, if the quality of products or services provided meets customer expectations will lead to customer satisfaction, otherwise, they will lead to customer dissatisfaction. If the quality is improved but not based on the needs of the customer, the customer will never be satisfied with that service. Therefore, when using the service, if customers feel the service is of high quality, they will be satisfied and vice versa. Therefore, the quality of products and services plays an important role in bringing satisfaction to customers.

\section{The service quality gap model of Parasura- man et al}

Customers' expectations for service quality are at a distance from their perception of that service quality. Parasuraman et al. (1988) ${ }^{1}$ proposed the following five service quality gap model:

- The first gap is the discrepancy between the managers' perceptions and customers' expectations.

- The second gap is created when the supplier conveys the supplier's perceived expectations to the quality criteria that meet the customer's expectations.

- When the result of service provision is below the standard level, the third distance appears. 
- The fourth gap is the discrepancy between the information informed to the customer and the service delivery.

- The fifth gap appears when there is a difference between the expected quality from the customer and the quality they have felt.

This model has the advantage of covering all aspects of the service, but it has the disadvantage of being difficult to evaluate, measure and analyze. Moreover, this model is theoretical, so there may be many components that are not discriminatory, so in 1988, Parasuraman made many adjustments and came to the conclusion that the service quality consisted of five components.

Berry and Parasuraman (1991) ${ }^{13}$ built the final SERVQUAL scale to evaluate service quality including 22 variables of 5 components to measure the expected quality and perceived service shown as follows: reliability, responsiveness, assurance, empathy and tangible facilities.

However, the use of SERVQUAL needs to be adjusted to suit the different types of services and markets that the study is aiming at, so the number of observed variables and content will change accordingly.

\section{RESEARCH MODEL}

\section{Research process}

Preliminary research (qualitative research) was conducted to establish and complete the questionnaire. The study was conducted through direct survey of customers who have been using the service at Techcombank - An Giang.

In-depth interviews are questions that based on theory and practical information, and used to find more information around research topics. After completing the questionnaire, will check, evaluate the rationality, adjust and complete.

Conducting a formal survey is using a completed questionnaire. The collected data will be carried out for cleaning, coding and conducting analysis.

\section{Research model}

There are many models for assessing service quality, of which the most widely used are Expectation model - perceived level (SERVQUAL), Sensitive level model (SERVPERF) and tissue the importance model - the degree of representation, the model of the degree of expectation - the degree of representation (SERVQUAL - Service Quality) proposed by Berry and Parasuraman (1991). SERVQUAL scale measures the perceive through 5 components of service quality (Figure 1), including: (1) Reliability: Demonstrate the ability to deliver appropriate and timely services at the first time; (2) Responsibility: Demonstrate willingness of service staff to provide timely service to customers; (3) Asurance: Demonstrate professional qualifications and courteous and hospitable service to customers; (4) Empathy: Show caring for each individual customer; (5) Tangibles: Expressed through appearance, service attire, equipment to perform the service (Table 1).

Measuring service quality according to SERVPERF model of Cronin Jr and Taylor (1992) ${ }^{11}$ is considered as a more convenient method, because the questionnaire is concise, saves time and avoids misleading respondents. The downside of this model is that it does not reflect the relationship between user satisfaction and satisfaction and the quality of service provided. Therefore, nowadays studies on customer satisfaction still use SERVQUAL model.

In Vietnam, Loan (2008) ${ }^{14}$, Đ. P. Hổ (2009) ${ }^{15}$, Đ. P. Hổ and HUÊ (2019) ${ }^{16}$ have based on the theory of Berry and Parasuraman (1991) ${ }^{13}$ to build the model studies the factors affecting customer satisfaction at commercial banks.

The paper will use SERVQUAL to assess and verify the service quality of Techcombank - An Giang.

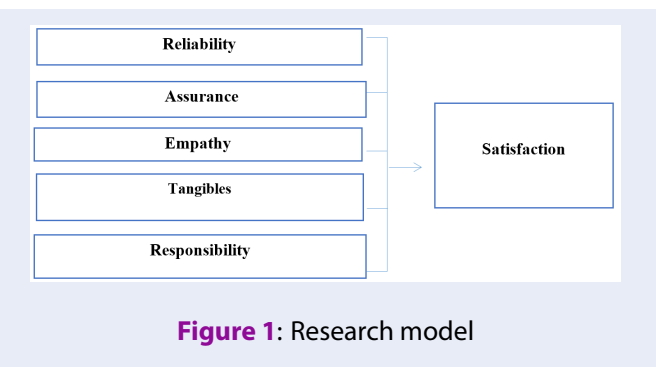

The paper will use Liker scale from 1 to five to meansure the Interpret observed variables of the service quality at Techcombank - An Giang (Table 1).

\section{Research hypotheses}

$\mathrm{H} 1$ : Tangibles is positively related to satisfaction, meaning the higher the tangible means of service are rated by customers, the higher the satisfaction of service quality and vice versa.

$\mathrm{H} 2$ : Reliability is positively related to satisfaction, which is the higher the reliability of the service is, the higher the satisfaction of service quality is and vice versa.

H3: Responsibility is positively related to satisfaction, which is the higher the satisfaction of customer service, the higher the satisfaction of service quality is and vice versa. 
Table 1: Interpret observed variables in the research model

\begin{tabular}{|c|c|c|c|}
\hline \multicolumn{2}{|l|}{ Factors } & \multirow{2}{*}{$\begin{array}{l}\text { Observed variables } \\
\text { Techcombank strictly follows its commitments }\end{array}$} & \multirow{2}{*}{$\begin{array}{l}\text { Scale type } \\
\text { Liker } 1-5\end{array}$} \\
\hline Reliability & REL1 & & \\
\hline & REL2 & Your information is kept confidential as prescribed & Liker $1-5$ \\
\hline & REL3 & Techcombank is your trusted bank & Liker $1-5$ \\
\hline & REL4 & Techcombank makes the first transaction right & Liker $1-5$ \\
\hline & REL5 & Safety when making transactions at Techcombank & Liker $1-5$ \\
\hline \multirow[t]{6}{*}{ Responsibility } & RES1 & Processing time at Techcombank is very fast & Liker $1-5$ \\
\hline & RES2 & Staff are always ready to listen, to meet your needs & Liker 1 - 5 \\
\hline & RES3 & taff instructed you to conduct the transaction enthusiastically & Liker $1-5$ \\
\hline & RES4 & Wide and convenient transaction network & Liker $1-5$ \\
\hline & RES5 & Staff always answer the phone and email quickly & Liker $1-5$ \\
\hline & RES6 & Convenient working time & Liker $1-5$ \\
\hline \multirow[t]{5}{*}{ Empathy } & EMP1 & Staff often ask you about customer service & Liker $1-5$ \\
\hline & EMP2 & Staff treat you properly & Liker 1 - 5 \\
\hline & EMP3 & taff understands your specific needs & Liker $1-5$ \\
\hline & EMP4 & taff is actively concerned about customer difficulties & Liker $1-5$ \\
\hline & EMP5 & taff is enthusiastic and friendly & Liker $1-5$ \\
\hline \multirow[t]{4}{*}{ Assurance } & ASS1 & taff is very happy and enthusiastic when you enters Techcombank & Liker $1-5$ \\
\hline & ASS2 & Staff answered your questions clearly and satisfactorily & Liker $1-5$ \\
\hline & ASS3 & Staff deal with customers' transactions very quickly and accurately & Liker $1-5$ \\
\hline & ASS4 & Staff with high professional knowledge & Liker $1-5$ \\
\hline \multirow[t]{5}{*}{ Tangibles } & TAN1 & Transaction counters are arranged logically and impressively & Liker $1-5$ \\
\hline & TAN2 & Techcombank's equipment is modern and attractive & Liker $1-5$ \\
\hline & TAN3 & Professional and impressive staff attire & Liker $1-5$ \\
\hline & TAN4 & Good facilities (toilet, TV, newspaper, drinking water, etc.) & Liker $1-5$ \\
\hline & TAN5 & Parking is very convenient and safe & Liker 1 - 5 \\
\hline \multirow[t]{4}{*}{ Satisfaction } & SAT1 & You are satisfied with the facilities of Techcombank & Liker $1-5$ \\
\hline & SAT2 & You feel satisfied when dealing with Techcombank & Liker $1-5$ \\
\hline & SAT3 & You will introduce to your friends about the service at Techcombank & Liker $1-5$ \\
\hline & SAT4 & You will continue to use Techcombank's services in the future & Liker $1-5$ \\
\hline
\end{tabular}


H4: Assurance is positively related to satisfaction, which is the higher the service capacity of the customer service, the higher the satisfaction of service quality is and vice versa.

H5: Empathy is positively related to satisfaction, which is the higher the value of customer service empathy, the higher the satisfaction of service quality is and vice versa.

\section{RESULTS AND DISCUSSION}

The survey was conducted in the period from March to April 2019, conducted through the distribution of questionnaires directly to customers who have used the service at Techcombank. As a result, 207 satisfactory surveys of 220 questionnaires were distributed. The data is analyzed and reported.

\section{Sample information by Age}

The study results showed that the majority of the interviewees were young people, about 18 to 30 years old, account for $53 \%$ (110 people) (Table 2 ). The age group of $31-40$ account for $16 \%$ (34 people). Then, the age group from $41-50$ years old account for $30 \%$ (61 people). And the age group 50 and older is quite small with only $1 \%$ (Table 2 ).

\begin{tabular}{lll} 
Table 2: Sample Information by Age & \\
\hline Age & Peoples & Percentages \\
From 18 to 30 & 110 & $53 \%$ \\
From 31 to 40 & 34 & $16 \%$ \\
From 41 to 50 & 61 & $30 \%$ \\
From 50 and older & 2 & $1 \%$ \\
Total & 207 & $100 \%$ \\
\hline
\end{tabular}

\section{Sample information by Gender}

Table 3: Sample information by gender

\begin{tabular}{lll}
\hline Gender & Peoples & Percentages \\
Male & 86 & $42 \%$ \\
Female & 115 & $58 \%$ \\
Total & 207 & $100 \%$ \\
\hline
\end{tabular}

Based on Table 3, there is a big difference between male and female. Among 207 people surveyed, there were 86 males (accounting for 42\%) and 115 females (accounting for 58\%) (Table 3).

\section{Reliability test results with Cronbach's AI- pha}

Cronbach's Alpha if Item deleted REL3 (0.658) is bigger than Cronbach's Alpha (0.656); Cronbach's
Alpha if Item deleted EMP5 (0.839) is bigger than Cronbach's Alpha (0.815); Cronbach's Alpha if Item deleted TAN5 (0.865) is bigger than Cronbach's Alpha (0.842) (Table 4). However, the Corrected Item-Total Correlation of REL3, EMP5 and TAN5 is greater than 0.3 . So these observed variables are retained for further analysis.

After completing the scale test using Cronbach's Alpha coefficient, the number of observed variables remain 29 variables, and 5 independent variables (Reliability, Responsibility, Empathy, Assurance, Tangibles). The dependent variable is satisfaction.

\section{Results of Exploratory Factor Analysis (EFA)}

Cronbach's Alpha coefficient test results are used for discovery factor analysis (EFA). After four analyzes, the results obtained from the initial 25 observed variables are grouped into 5 factors with 16 observed variables.

\section{The results of EFA for the service quality fac- tors scale}

+ The results of EFA - First times

$\mathrm{KMO}$ and Bartlett's tests in factor analysis showed that $\mathrm{KMO}$ coefficient is $0.873>0.5$ with sig significance level. $=0.000$. Thus, the factors qualify for EFA.

Based on the results of the sample matrix, the observed variables ASS2, TAN5, REL4, RES5, ASS1 have factor loading $<0.3$, so it is not eligible for factor analysis. Based on the results of the total variance explained at the level of Eigenvalues greater than 1, the analysis table is extracted four groups of factors from the 25 observed variables with extracted variance of $60.527 \%$ satisfactory because it is greater than $50 \%$ (Figure 2) .

The results of the first times (EFA) showed that out of 25 observed variables, there were 6 unsatisfactory variables, the remaining 19 variables continued to conduct the second times EFA.

+ The results of EFA - Second times

$\mathrm{KMO}$ and Bartlett's tests in factor analysis showed that KMO coefficient is $0.856>0.5$ with sig significance level. $=0.000$. Thus, the factors qualify for EFA.

Based on the results of the sample matrix, the observed variables RES3, ASS4 have factor loading $<0.3$, so it is not eligible for factor analysis. Based on the results of the total variance explained at the level of Eigenvalues greater than 1, the analysis table is extracted four groups of factors from the 19 observed variables with extracted variance of $55.768 \%$ satisfactory because it is greater than $50 \%$ (Figure 2). 
Table 4: Summary results of Cronbach's Alpha coefficients

\begin{tabular}{|c|c|c|c|c|c|}
\hline Factors & $\begin{array}{l}\text { Scale Mean if } \\
\text { Item Deleted }\end{array}$ & $\begin{array}{l}\text { Scale Variance } \\
\text { if Item Deleted }\end{array}$ & $\begin{array}{l}\text { Corrected Item- } \\
\text { Total Correlation }\end{array}$ & $\begin{array}{l}\text { Cronbach's Alpha } \\
\text { if Item Deleted }\end{array}$ & $\begin{array}{l}\text { Cronbach's } \\
\text { Alpha }\end{array}$ \\
\hline REL1 & 17.02 & 4.029 & 0.390 & 0.613 & 0.656 \\
\hline REL2 & 17.45 & 3.744 & 0.330 & 0.644 & \\
\hline REL3 & 17.33 & 3.727 & 0.310 & 0.658 & \\
\hline REL4 & 17.04 & 3.576 & 0.534 & 0.547 & \\
\hline REL5 & 17.20 & 3.580 & 0.529 & 0.549 & \\
\hline RES1 & 21.32 & 6.480 & 0.620 & 0.761 & 0.805 \\
\hline RES2 & 21.49 & 6.319 & 0.616 & 0.761 & \\
\hline RES3 & 21.36 & 6.163 & 0.685 & 0.744 & \\
\hline RES4 & 21.29 & 7.515 & 0.412 & 0.804 & \\
\hline RES5 & 21.26 & 7.242 & 0.470 & 0.793 & \\
\hline RES6 & 21.50 & 6.329 & 0.570 & 0.774 & \\
\hline EMP1 & 15.80 & 6.143 & 0.751 & 0.731 & 0.815 \\
\hline EMP2 & 15.69 & 6.556 & 0.697 & 0.751 & \\
\hline EMP3 & 15.59 & 7.116 & 0.592 & 0.783 & \\
\hline EMP4 & 15.69 & 6.886 & 0.620 & 0.775 & \\
\hline EMP5 & 15.30 & 8.329 & 0.372 & 0.839 & \\
\hline ASS1 & 12.72 & 2.492 & 0.556 & 0.618 & 0.715 \\
\hline ASS2 & 12.57 & 2.799 & 0.538 & 0.633 & \\
\hline ASS3 & 12.38 & 2.888 & 0.469 & 0.671 & \\
\hline ASS4 & 12.48 & 2.775 & 0.451 & 0.684 & \\
\hline TAN1 & 15.87 & 8.081 & 0.668 & 0.806 & 0.842 \\
\hline TAN2 & 16.13 & 6.949 & 0.705 & 0.794 & \\
\hline TAN3 & 16.16 & 6.730 & 0.733 & 0.786 & \\
\hline TAN4 & 15.94 & 7.370 & 0.758 & 0.779 & \\
\hline TAN5 & 15.53 & 9.484 & 0.398 & 0.865 & \\
\hline SAT1 & 12.88 & 2.573 & 0.509 & 0.729 & 0.760 \\
\hline SAT2 & 12.73 & 2.390 & 0.583 & 0.690 & \\
\hline SAT3 & 12.88 & 2.355 & 0.577 & 0.693 & \\
\hline SAT4 & 12.81 & 2.506 & 0.564 & 0.701 & \\
\hline
\end{tabular}



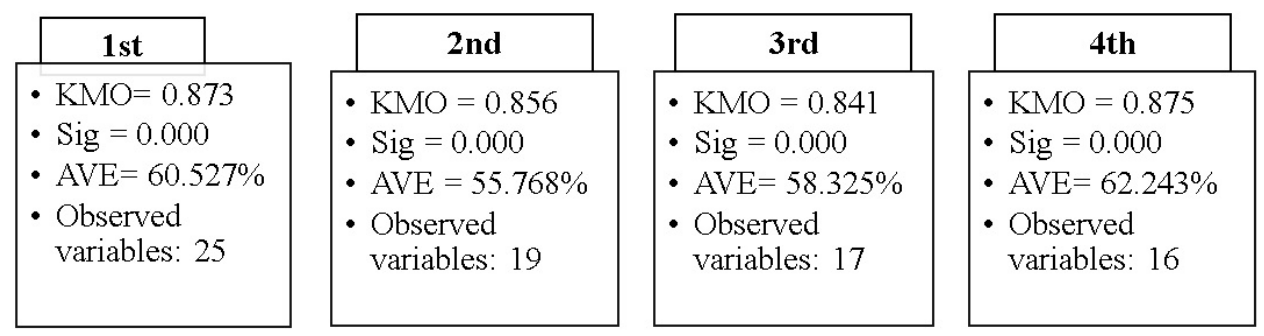

Figure 2: Results of Exploratory Factor Analysis

The results of the second times (EFA) showed that out of 19 observed variables, there were 2 unsatisfactory variables, the remaining 17 variables continued to conduct the third times EFA.

+ The results of EFA - Third times

$\mathrm{KMO}$ and Bartlett's tests in factor analysis showed that KMO coefficient is $0.841>0.5$ with sig significance level. $=0.000$. Thus, the factors qualify for EFA.

Based on the results of the sample matrix, the observed variables ASS3 has factor loading $<0.3$, so it is not eligible for factor analysis. Based on the results of the total variance explained at the level of Eigenvalues greater than 1 , the analysis table is extracted four groups of factors from the 17 observed variables with extracted variance of $58.325 \%$ satisfactory because it is greater than $50 \%$. (Figure 2)

The results of the third times (EFA) showed that out of 17 observed variables, there were 1 unsatisfactory variable, the remaining 16 variables continued to conduct the fourth times EFA.

+ The results of EFA - Fourth times

KMO and Bartlett's tests in factor analysis showed that KMO coefficient $=0.875>0.5$ with sig significance level. $=0.000$. Thus, the factors qualify for EFA. (Figure 2 )

Based on the results of the sample matrix, the observed variables have factor loading $>0.3$, so it is eligible for factor analysis. Based on the results of the total variance explained at the level of Eigenvalues greater than 1 , the analysis table is extracted four groups of factors from the 16 observed variables with extracted variance of $60.243 \%$ satisfactory because it is greater than $50 \%$.

After 4 times of EFA, there are 4 groups of factors extracted from the model. (Table 5)

The first group of factors includes 5 observed variables EMP2, EMP1, EMP4, EMP3 and EMP5.

The second group of factors includes 4 observed variables TAN3, TAN4, TAN2, and TAN1.
The third group of factors includes 4 observed variables RES1, RES2, RES6, and RES4.

The fourth group of factors includes 3 observed variables REL1, REL5, and REL2.

\section{The results of EFA for the satisfaction scale}

$\mathrm{KMO}$ and Bartlett's tests in factor analysis for satisfaction show that KMO coefficient is 0.723 greater than 0.5 , sig significance level. is $0.000<0.05$. Therefore, the basis of variables is correlated with each other and suitable for EFA analysis (Table 6).

Eigenvalue coefficient of components greater than 1, with extract variance, is $58.182 \%$ greater than $50 \%$, so it meets the requirements.

Factor loading of observed variables is greater than 0.4 , so it meets the requirement in factor analysis.

\section{Table 6: Results of EFA of customer satisfaction}

\begin{tabular}{ll}
\hline Observed variables & Factor \\
& SAT \\
SAT2 & 0.781 \\
SAT3 & 0.780 \\
SAT4 & 0.767 \\
SAT1 & 0.721 \\
Eigenvalue & 2.327 \\
AVE $(\%)$ & 58.182 \\
KMO: 0.781 & Sig. 0.000 \\
\hline
\end{tabular}

\section{Regression analysis results}

Regression analysis results show that the $\mathrm{R}^{2}$ adjusted is 0.411 means that $41.1 \%$ of customer satisfaction variation is explained by 4 independent variables EMP, TAN, RES, REL while $58.9 \%$ of customer satisfaction variation is solved by factors outside the model, the remaining other factors have not been 


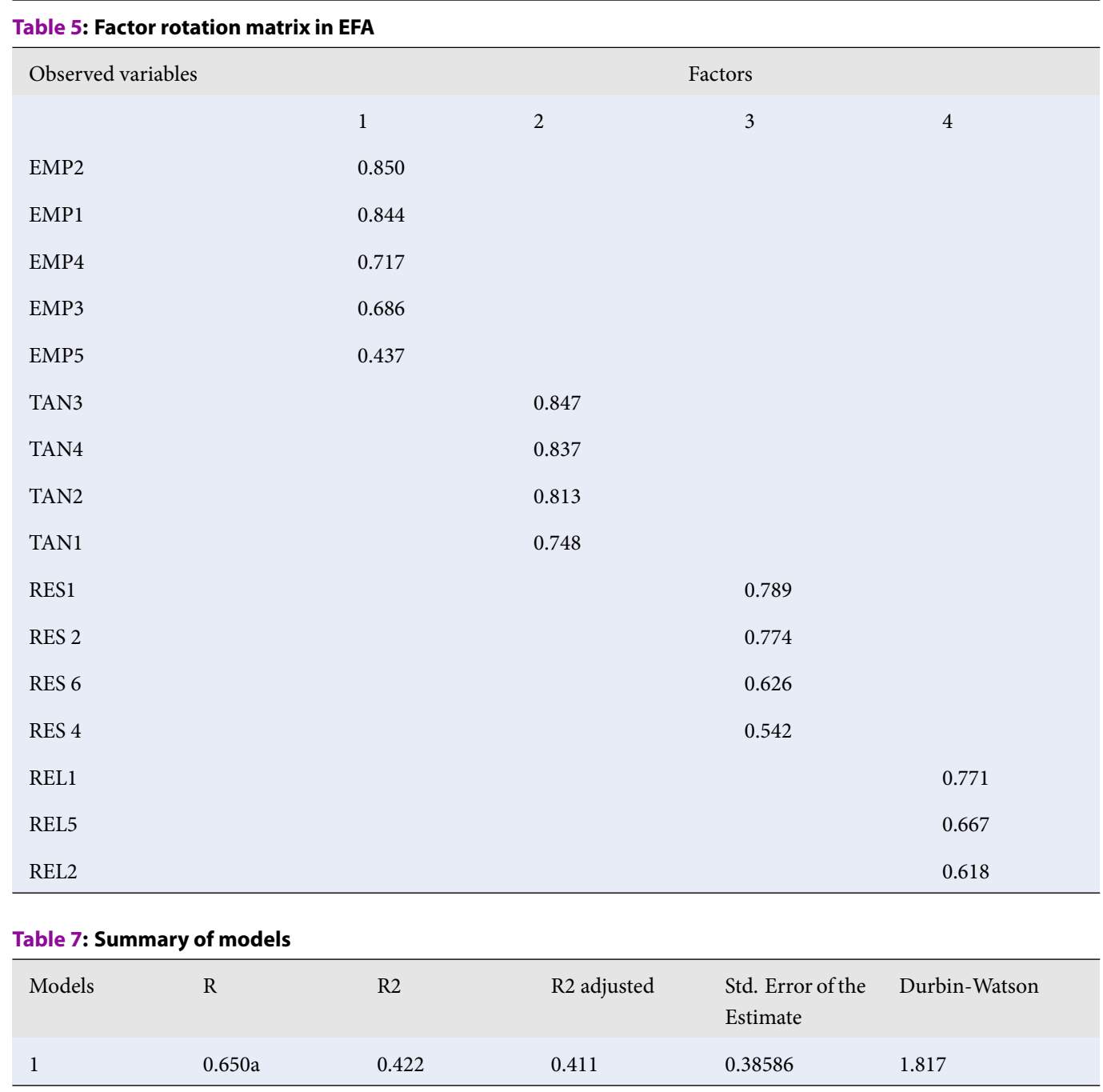

studied. The coefficient Sig.F $=0.00$ is much smaller than the significance level of $\alpha=5 \%$ (Table 7). So, the regression model makes sense, which means that the independent variables influence the dependent variable.

The Durbin-Watson coefficient of the model is 1,817 , indicating that the model has no autocorrelation phenomenon (Hoàng \& Chu, 2008) ${ }^{17}$. In addition, the variance magnification (VIF) of variables in the model is many times smaller than 10 , so we conclude that the variables included in the model do not have multicollinear phenomena. The analysis results also show that, among the 4 variables EMP, TAN, RES, REL included in the model, all 4 variables are statistically significant.

Testing the hypothesis of the suitability of the model by testing F. shows that the F-test has Sig $=0.000$, proving that the set linear regression model is suitable for the data set as well as the independent variables in the model, which can explain for the change of the dependent variable.

The regression weight table is considered because the weight $\beta$ (Table 8 ) of these variables is statistically significant (Sig. $=0.00<0.05$ ). Therefore, variables EMP, TAN, RES, REL have effects on the variable SAT.

Thus, the linear regression equation (Table 8) is rewritten as follows:

$\mathrm{SAT}=0.253 \mathrm{EMP}+0.235 \mathrm{TAN}+0.248 \mathrm{RES}+0.144$ REL

The regression results show that the independent variables EMP, TAN, RES, REL having Beta coefficients, respectively, $0.253 ; 0.235 ; 0.248 ; 0.144$ all have positive signs, so all variables have the same effect with customer satisfaction on service quality at Techcombank - An Giang.

It can be concluded that the suitability of theoretical model for the data, and hypotheses $\mathrm{H} 1, \mathrm{H} 2, \mathrm{H} 3, \mathrm{H} 4$ 


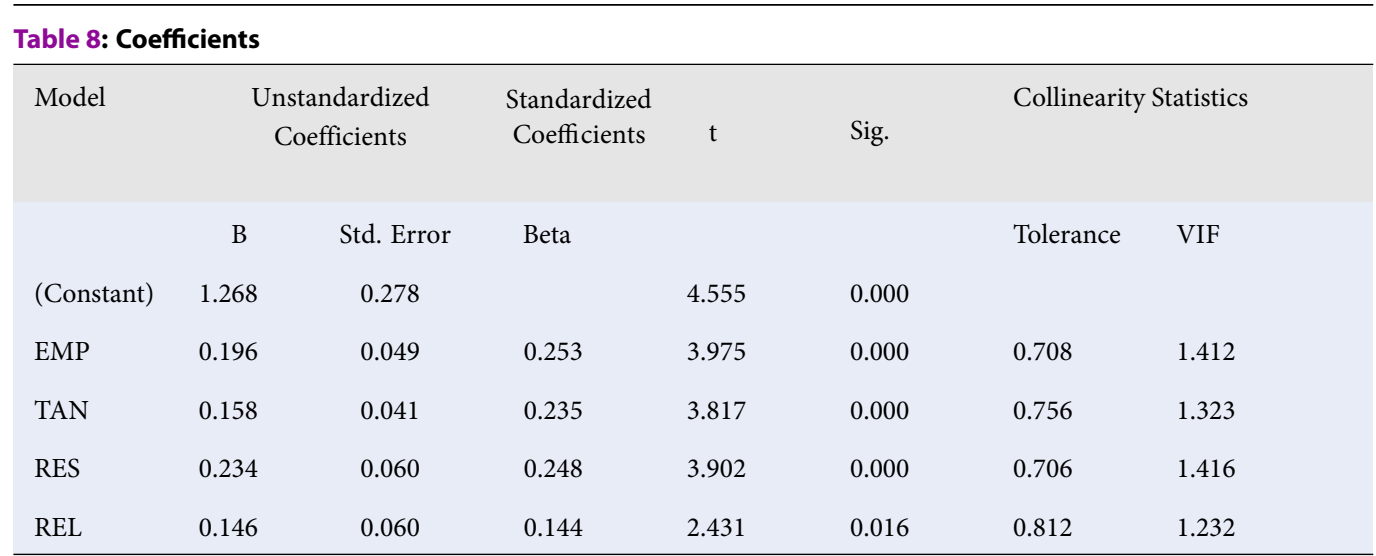

are accepted. The results show that there are 4 independent variables with significant effects on the dependent variable $(\mathrm{sig}<0.05)$. And the remaining 4 factors included in the regression analysis are retained in the model.

\section{Current status of customer satisfaction on service quality at Techcombank - An Giang}

Through Figure 3, customers highly appreciate Techcombank's service quality with an average of 4.03 to 4.49 , of which customers rated the reliability best (average 4.49). This shows that this is a strength of Techcombank - An Giang because of the reputation and outstanding service quality make customers highly satisfied (Figure 3).

Along with the reliability, the responsiveness, also highly appreciated, ranked second with an average value of 4.36, shows that service efficiency is also a strength that Techcombank needs to pay attention to maintain customers' trust.

Ranking third in customer evaluation is the average sympathy of 4.21 , which is quite a high number, proving that customers are also very satisfied with the attentive, and care that Techcombank's employees distributed. Therefore, the bank needs to have training and remuneration policies for employees to improve customer satisfaction for Techcombank - An Giang. Although ranked lowest among the four scales, the tangible vehicle component is rated at a high level (average of 4.03) with modern facilities. This proves that Techcombank's service quality is relatively good and meets the needs of customers.

\section{CONCLUSION}

The results of the current situation analysis of factors affecting customer satisfaction show that reliability is the highest rated customer with an average of 4.49 . The second most appreciated factor is the responsiveness with an average of 4.36 , not much different from the reliability factor. The third most appreciated is the empathy with the average of 4.21 . The lowest rated element is the tangible means with an average of 4.03 , but still high.

Besides, the regression analysis results (Table 8) show that the level of impact of 4 factors on customer satisfaction, in which empathy (0.253) has the largest impact on customer satisfaction, has second most significant effect is responsibilities (0.248), ranking third in terms of influence is tangible means (0.235), and finally reliability $(0.144)$ having the lowest influence among the four factors.

In summary, the research results have basically achieved the initial goal of analyzing the factors affecting customer satisfaction when using services at Techcombank - An Giang.

Through the research results, the author would like to propose some ideas to improve the service quality, thereby, attract new customers and the important thing is to keep traditional customers because the development orientation of Techcombank - An Giang is to take care of old customers to cross sell other products of the bank as follows:

\section{Improve satisfaction with the element of Empathy}

Pay attention to customers during the transaction process with dedicated service, customer inquiries, and affable attitude. Staff should try to remember the customer's name as much as possible, which makes customers feel appreciated.

The bank should allow employees to attend training courses on communication skills, customer care and understanding, which will help customers feel confident when using the service at the bank. 
4.6
4.5
4.4
4.3
4.2
4.1
4
3.9
3.8

4

\subsection{9}

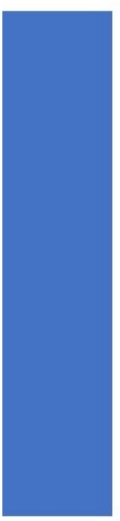

Rel

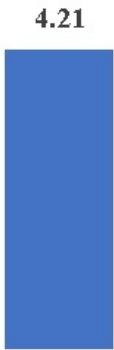

Emp

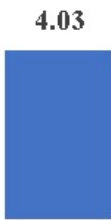

Tan

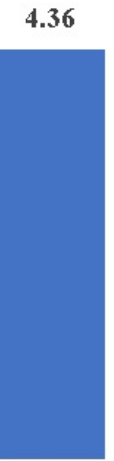

Res

Figure 3: Current status of customer satisfaction on service quality at Techcombank - An Giang

Improve satisfaction with the element of Responsibility

It is necessary to simplify the procedures, automate the execution, and ensure accuracy and timeliness to minimize customer transaction time and build trust in customers.

Expand the transaction network on the provincial area to facilitate the transaction needs of customers in the province.

Improve service quality based on customer feedback. Feedbacks from customers should be respected, preferably thanks.

\section{Improve satisfaction with Tangibles}

Banks need to invest in the appearance of transaction offices, especially in the layout of luxurious, neat space, eye-catching design, a convenient and safe parking lot.

In addition, a table of water with a vase and a few magazines introducing banks, a few small services while waiting for transactions are also an effective way to hold customers.

\section{Improve satisfaction with the reliability}

Improving bank's reputation is a top priority. It takes a long period of time to gain customers' trust, to build and retain customers.

Enhance the sense of banking security in the minds of customers such as investing in facilities, carrying out accurate transactions, making financial transparency and effective business.
Update information quickly, promptly and accurately, and provide complete information quickly to customers.

\section{ABBREVIATIONS}

ASS: Assurance

AVE: Average

EFA: Exploratory Factor Analysis

EMP: Empathy

KMO: Kaiser-Meyer-Olkin (KMO) Test

REL: Reliability

RES: Responsibilities

SAT: Satisfaction

Sig: Significant

TAN: Tangibles

\section{ACKNOWLEDGEMENT}

The authors would like to thank the Board of Directors, and the entire staff for Techcombank An Giang for supporting the team to complete this study.

\section{CONFLICTS OF INTEREST}

The authors declare that they have no conflicts of inerest

\section{AUTHORS' CONTRIBUTION}

The content of the article is studied by the authors: Tran Minh Hieu: Study the revision of the research model, write a draft of the results, and review the final results.

Nguyen Duong Ngoc Mai Chi: Support for reviewing, surveying data, analyzing results and writing reports. 


\section{REFERENCES}

1. Parasuraman A, ZeithamI VA, Berry L. Servqual: A multipleitem scale for measuring consumer perc. Journal of Retailing Spring. 1988;64(1):12.

2. Armstrong G, Adam S, Denize S, Kotler P. Principles of marketing. 7th ed. Australia: Pearson. 2014;

3. Asubonteng P, McCleary KJ, Swan JE. SERVQUAL revisited: a critical review of service quality. Journal of services Marketing. 1996;10(6). Available from: https://doi.org/10.1108/ 08876049610148602.

4. Bachelet D. Measuring Satisfaction or the Chain, the Tree and the Nest. Marketing research congress. 1992;p. 229-258.

5. Oliva TA, Oliver RL, Bearden WO. The relationships among consumer satisfaction, involvement, and product performance: A catastrophe theory application. John Wiley \& Sons. 1995;40(2):104-132. Available from: https://doi.org/10.1002/ bs.3830400203.

6. Oliver RL. Satisfaction: A Behavioral Perspective on the Consumer. International Journal of Research Studies in Management. 1997;p. 75-82.

7. Zeitham VA, Bitner MJ, Gremler DD, Pandit A. Services marketing: Integrating customer focus across the firm. New York: McGraw-Hill Irwin. 2000;

8. Philip K, Gary A, John S, Veronica W. Principles of marketing/third european edition. London: Prentice Hall. 2001;

9. Tse DK, Wilton P. Models of consumer satisfaction formation: An extension. Journal of Marketing Research. 1988;25(2):204-212. Available from: https://doi.org/10.1177/

\section{9}

10. Shemwell DJ, Yavas U, Bilgin ZJ. Customer-service provider relationships: an empirical test of a model of service quality, satisfaction and relationship-oriented outcomes. International Journal of Service Industry Management. 1998;p. 155-168. Available from: https://doi.org/10.1108/09564239810210505.

11. Cronin JJ, Taylor SA. Measuring service quality: a reexamination and extension. Journal of Marketing. 1992;56(3):55-68. Available from: https://doi.org/10.1177/002224299205600304.

12. Curry A, Sinclair E. Assessing the quality of physiotherapy services using SERVQUAL. International Journal of Health Care Quality Assurance. 2002;15(5):197-205. Available from: https: //doi.org/10.1108/09526860210437412.

13. Berry LL, Parasuraman AJCT. Managing services. Academy of Management Executives. 1991;p. 32-52.

14. Loan HXB. Nâng cao sự hài lòng của khách hàng tại Ngân Hàng Đầu Tư và Phát Triển Việt Nam Chi nhánh Thành phố Hồ Chí Minh. Trường Đại học Kinh tế thành phố Hồ Chí Minh. 2008;.

15. Hổ PD. Mô hình định lượng đánh giá mức độ hài lòng của khách hàng ứng dụng cho hệ thống ngân hàng thương mại. Tạp chí Tài chính. 2009;(26):7-12.

16. Hổ PD, HUÊ TT. Factors Affecting Customer Satisfaction: Case Study Of Hcmc Branch Of Vietinbank. Vietnam Journal Online. 2019;p. 16-20.

17. Hoàng $T$, Chu NMN. Phân tích dữ liệu nghiên cứu với SPSS-tập 1. Trường Đại học Kinh tế thành phố Hồ Chí Minh: Hồng Đức 2008;. 


\title{
Đo lường sự hài lòng của khách hàng về chất lượng dịch vụ tại ngân hàng thương mại cổ phần Kỹ Thương Việt Nam - chi nhánh An Giang
}

\author{
Trần Minh Hiếu ${ }^{1, *}$, Nguyễn Dương Ngọc Mai Chi
}

${ }^{1}$ Trường Đai họ An Giang,

ĐHQG-HCM, Phòng NB105, Số 18 Đường Ung Văn Khiêm, Phuiờng Đông Xuyên, Thành phố Long Xuyên, Tỉnh An Giang, Viẹt Nam

${ }^{2}$ Ngân hàng Bản Việt - Chi nhánh An Giang, 350 Đường Nguyễn Huệ, Thị trấn Núi Sập, Huyện Thoại Sơn, Tỉnh An Giang, Việt Nam

Liên hệ

Trần Minh Hiếu, Trường Đại học An Giang, ĐHQG-HCM, Phòng NB105, Số 18 Đường Ung Văn Khiêm, Phường Đông Xuyên, Thành phố Long Xuyên, Tinh An Giang, Việt Nam

Email: tmhieu@agu.edu.vn

Lịch sử

- Ngày nhận: 02/01/2020

- Ngày chấp nhận: 17/5/2020

- Ngày đăng: 11/9/2020

DOI : 10.32508/stdjelm.v4i3.657

\section{Check for updates}

\section{Bản quyền}

๑ Đ ĐHQG Tp.HCM. Đây là bài báo công bố mở được phát hành theo các điều khoản của the Creative Commons Attribution 4.0 International license.

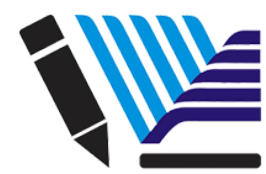

VNU-HCM Press

\section{TÓM TẮT}

Nghiên cứu này áp dụng thang đo SERVQUAL của Parasuraman và cộng sự để đo lường các yếu tố tác động đến sự hài lòng của khách hàng về chất lượng dịch vụ tại ngân hàng thương mại cổ phần Kỹ thương Việt Nam Chi nhánh An Giang (Techcombank An Giang). Nghiên cứu được tiến hành thực hiện khảo sát 207 khách hàng đã và đang sử dụng dịch vụ tại Techcombank An Giang. Kết quả khảo sát được tiến hành phân tích bằng phương pháp kiểm tra độ tin cậy thang đo Cronbach's Alpha, sau đó tiển hành phân tích nhân tố khám phá (EFA) để kiểm định và đánh giá thang đo về chất lượng dịch vụ. Kết quả phân tích hồi quy cho thấy sự hài lòng của khách hàng về chất lượng dịch vụ tại Techcombank An Giang bao gôm: Nhân tố có mức độ cao nhất là Sự đồng cảm có hệ số beta $=0.253$, thứ hai là nhân tố Sự đáp ứng (beta $=0.248$ ), xếp thứ ba về mức độ ảnh hưởng là nhân tố Phương tiện hữu hình (beta $=0.235$ ) và mức độ tác động thấp nhất là nhân tố Độ tin cậy (beta $=0.144$ ). Nghiên cứu còn sử dụng phương pháp thống kê mô tả và kiểm định sự khác biệt các yếu tố nhân khẩu học. Kết quả phân tích cho thấy không có sự khác biệt giữa sự hài lòng khách hàng vềchất lượng dịch vụ với các yếu tố như: giới tính, độ tuổi, thu nhập, số lượng ngân hàng giao dịch, ngân hàng giao dịch thường xuyên nhất và thời gian sử dụng dịch vụ tại Techcombank. Qua kết quả nghiên cứu, tác giả xin đề xuất một số ý kiến nhằm cải tiến chất lượng dịch vụ, qua đó thu hút được khách hàng mới và quan trọng là giữ được khách hàng truyền thống vì định hướng phát triển của Techcombank là chăm sóc khách hàng cũ để bán chéo những sản phẩm khác của ngân hàng. Nghiên cứu sẽ là cơ sở để giúp Techcombank An Giang nhận biết được các nhân tố ảnh hưởng đến sự hài lòng của khách hàng về chất lượng dịch vụ tại ngân hàng từ đó có chiến lược nâng cao chất lượng dịch vụ phù hợp nhằm đáp ứng sự hài lòng của khách hàng.

Từ khoá: Sự hài lòng khách hàng, Techcombank - An Giang, chất lượng dịch vụ
Trích dẫn bài báo này: Hiếu T M, Chi N D N M. Đo lường sự hài lòng của khách hàng về chất lượng dịch vụ tại ngân hàng thương mại cổ phần Kỹ Thương Việt Nam - chi nhánh An Giang. Sci. Tech. Dev. J. -Eco. Law Manag.; 4(3):897-908. 